\title{
NEUTROPHIL-TO-LYMPHOCYTE RATIO AND PROGNOSIS OF SPONTANEOUS INTRACEREBRAL
} HEMORRHAGE

\author{
Mehmet Yasir PEKTEZEL*, Ethem Murat ARSAVA*, Doğan Dinç ÖGE*, \\ Özlem KAYIM YILDIZ**, Mehmet Akif TOPÇUOĞLU* \\ *Hacettepe University Hospitals, Department of Neurology and Neurological Intensive Care Unit, \\ Ankara, TURKEY \\ **Cumhuriyet University Medical Faculty, Department of Neurology, Sivas, TURKEY
}

\begin{abstract}
INTRODUCTION: Neutrophil to Lymphocyte Ratio (NLR) is suggested to predict functional outcomes and mortality at admission of patients with intracerebral hemorrhage (ICH). However, effect of timing of NLR measurement on prediction of mortality and expansion in ICH has not been clarified.

METHODS: From admission and 24th-hour blood samples, admission NLR (NLR-adm) and 24th-hour NLR (NLR-24th) was calculated as "absolute neutrophil count/lymphocyte count". Hematoma expansion was evaluated with the volume $(\mathrm{ABC} / 2)$ difference from admission cranial CT to follow-up one.

RESULTS: A total of 383 patients (41.7\% female, age, 65 \pm 13 ) were assessed. Of them, 251 (65.5\%) were discharged. The average hematoma volume was $32.8 \mathrm{cc}$ and $35.3 \mathrm{cc}$ in the first and second CT, respectively. The mean NLR was $8.2 \pm 10.3$ at admission and $16.6 \pm 15.7$ at 24 th hour. Only NLR-24th $(\beta=0.035$, OR: 1.036 (1.002-1.071), $p=0.04)$, hematoma volume at first CT $(\beta=0.012$, OR $1.012(0.999-1.024) p=0.067)$ and Hemphill score $(\beta=0.689$, OR $1.992(1.402-2.832) p<0.001)$ were found to be significantly related with mortality after adjusted to age (decade), atrial fibrillation, anticoagulant use and NLR-adm. An exploratory logistic regression analysis indicated that hematoma expansion greater than $12.5 \mathrm{cc}$ correlated to, albeit borderline, NLR-24th $(\beta=0.038$, OR=1.038 (95\%CI: $1.008-1.069)$ but not NLR-adm.

DISCUSSION and CONCLUSION: We found NLR-24th to be associated with higher mortality and greater hematoma expansion rate. This NLR increment, probably secondary to the stress response, in ICH can be considered as an epiphenomenon of worse prognosis.
\end{abstract}

Keywords: Stroke, adrenal, stress, complete blood count, pneumonia.

\section{NÖTROFIL-LENFOSIT ORANI VE SPONTAN INTRASEREBRAL KANAMA PROGNOZU}

\section{ÖZET}

GİRIŞ ve AMAÇ: İntraserebral kanamalı (ISSK) hastaların başvuru esnasında ölçülen "nötrofil lenfosit oranının (NLR)" fonksiyonel sonuçları ve mortaliteyi öngörmede kullanılabileceği belirtilmiştir. Bununla birlikte, NLR ölçümünün zamanlamasının, İSK'daki mortalite ve erken genişleme tahmini üzerindeki etkisi tam olarak netleşmemiștir.

YÖNTEM ve GEREÇLER: Giriș ve 24. saat kan örneklerinden, giriş NLR ("NLR-adm”) ve 24 saatlik NLR ("NLR-24"), "mutlak nötrofil sayısı / lenfosit sayısı" olarak hesaplandı. Hematom volümetrik genişlemesi, "geliş̧" ve 24. saatte çekilen "kontrol" BT arasındaki" ABC/2 formülü" ile hesaplanan hacimler arasındaki fark olarak alındı.

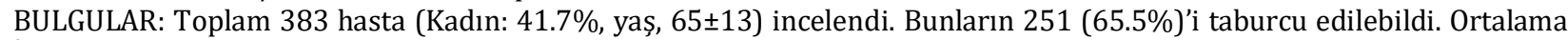

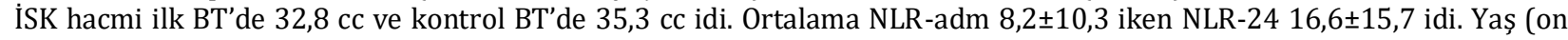
yıl), atriyal fibrilasyon ve antikoagülan kullanımına göre uyarlanarak yapılan regresyon analizinde NLR-24 $(\beta=0,035,0 R$ : 1,036 (1,002-1,071), $p=0,04)$, ilk BT'deki İSK hacmi $(\beta=0,012$, OR 1,012 (0,999-1,024) p=0,067) ve Hemphill skoru $(\beta=0.689$, OR 1,992 $(1,402-2,832) p<0,001)$ mortalite ile doğrudan bağlantılı bulunmuştur. Deneysel lojistik regresyon analizi ile 12,5 cc'den büyük hematom genișlemesinin, sinırda olsa da NLR-24 ( $\beta=0,038,0 R=1,038$ (95\%CI: 1,008-1,069)

\footnotetext{
Corresponding author: Mehmet Akif Topcuoglu, Prof. MD. Hacettepe University Hospitals, Department of Neurology and Neurological Intensive Care Unit, Ankara, TURKEY

Telephone: +903123051806 E-mail: matopcuoglu@yahoo.com

Received: $24.06 .2019 \quad$ Accepted: 19.08 .2019

This article should be cited as following: Pektezel M.Y, Arsava E.M, Öge D.D, Kayım Yıldız Ö, Topçuoğlu M.A. Neutrophil-to-lymphocyte ratio and prognosis of spontaneous intracerebral haemorrhage. Turkish Journal of Cerebrovascular Diseases 2019; 25 (2): 118-124. doi: 10.5505/tbdhd.2019.87587
} 
ile bağlantılı olduğu ama NLR-adm'in belirleyici rolü olmadığını göstermiştir. Yani, bu tam kan parametreleri ile gelişte hematom genișlemesi öngörülemez.

TARTIŞMA ve SONUÇ: 24. saatte bakılan NLR intraserebral kanama bağlamında mortalite artışı ve belki hematom genişlemesi ile ilişkilidir. Bu olasılıkla İSK'nın yarattığı stres reaksiyonunun derecesini yansıtan bir epifenomendir.

Anahtar Sözcükler: İnme, adrenal, stres, tam kan sayımı, pnömoni.

\section{INTRODUCTION}

Intracerebral Hemorrhage (ICH) is a devastating type of stroke with high rate of disability and mortality (1). It is known that both local and systemic inflammatory response are immediately triggered after stroke (2). Neutrophil to Lymphocyte Ratio (NLR) is an inexpensive and ready-to-use method to evaluate individual inflammatory status; and this method has been shown to be a marker for prediction of functional outcomes and mortality in coronary syndrome (3), ischemic stroke $(4,5)$, cancer (6), and ICH (7), as well. However, the association between NLR and intracerebral hematoma expansion has yet to be clarified. We herein aimed to document the effects of NLR, and its changes, on survival of patients with ICH and to explore whether there is an association between NLR and ICH expansion.

\section{MATERIAL AND METHODS}

Patients, data, measurements, scores: Sociodemographic, clinical and imaging data were extracted retrospectively with chart review, along with prospectively-gathered institutional stroke database running for the last ten years. Age $<18$ years and patients with secondary ICH were excluded. Clinical stroke severity was assessed with National Institutes of Health Stroke Scale (NIHSS) and Glasgow Coma Scale (GCS) at admission. Hemphill score (8) and STICH-2 prognosis score (STICH-2 PS) (9) were calculated. Of 413 patients detected via chart review, 334 had admission CT and 271 had 24th-hour follow-up cranial CT ready-to-our-review. Reasons for not performing follow-up CT may be early mortality, very good or moribund clinical status, or contraindication to transfer to CT suits. Exact duration of time intervals between symptom onset and first/second CTs could be obtained in only 133 patients. There was no significant difference between the main demographic variables of patients with and without follow-up CT (data not shown). Hematoma volume was calculated by the "AxBxC/2 formula" (10). NLR value was calculated as the absolute neutrophil count divided by the absolute lymphocyte count at the admission (NLRadm) and 24th hour (NLR-24th). NLR-adm and NLR-24th were available in 389 and 270 patients, respectively. The institutional review board approved the study protocol and the database.

Outcomes: Major outcome measures were "survival" at discharge and "hematoma expansion" on the first day. The survival status at discharge was tallied as "survived" and "expired". The hematoma expansion was calculated as the blood volume difference ("cubic centimeter-cc or milliliter" and percentage) between second and first CTs. Significant hematoma volume growth thresholds were set at " $12.5 \mathrm{cc}$ " and " $33 \%$ ".

Blood samples, hematological data: First blood samples were almost invariably obtained at the time of admission to emergency department while the second samples (at the end of the first day of ictus) were obtained at discretion of the treating physician. Complete blood count (CBC) results were collected via electronic chart review. Studied parameters and their normal ranges were: lymphocyte count, 1.2-3.6 $\left(10^{3} / \mu \mathrm{L}\right)$; neutrophil count, 1.8-6.4 (103/ $/ \mu \mathrm{L})$; monocyte count, 0.3-0.9 $\left(10^{3} / \mu \mathrm{L}\right)$; hemoglobin, 11.7-15.5 (gr/dL) and hematocrit 34.5-46.3 (\%). Normal limits of NLR were calculated as 0.5 to 5.3 .

Statistics: All values are represented as mean \pm standard deviation, 95\% confidence intervals $(95 \% \mathrm{CI})$, percentages, medians with interquartile ranges (IQR) as appropriate. Distribution normality was analyzed with the KolmogorovSmirnov and Shapiro-Wilk tests properly. Differences were tested with Mann-Whitney U / Student's t, paired t and Chi-square / Fisher's exact tests appropriately. Exploratory multivariate models to detect importance of NLR and other CBC parameters on survival and hematoma expansion were constructed. In these models, factors with $\mathrm{p}$ value less than 0.1 in the univariate phase were included into the multivariate steps. $\mathrm{P}<0.05$ was set as the statistical significance level. SPSS version 22 was used for all calculations. 


\section{RESULTS}

The mean age of entire study population was $65 \pm 13$ years and $41.7 \%$ were female. Symptom onset to first CT duration was $259 \pm 240$ minutes. The average hematoma volume was $32.8 \pm 37.1 \mathrm{cc}$ in the first CT. Mean duration from the initial to control CTs was $1663 \pm 1639$ minutes. The average hematoma volume was $35.3 \pm 38 \mathrm{cc}$ in the second CT.

Mean age, atrial fibrillation (AF), anticoagulant use, admission ICH volume (by approximately 20cc) and its enlargement during the first day (16.74 cc vs. $2.25 \mathrm{cc}$ ), admission SBP, NIHSS, GCS, Hemphill score and STICH-2 PS were significantly higher in 132 patients who died of ICH during hospital stay than those of 251 (65.5\%) who were successfully discharged (Table I).

Average NLR was $8.2 \pm 10.3$ at admission, and significantly increased to $16.6 \pm 15.7$ at the end of the first day. The increase in NLR was due to the increase of neutrophil count and, and perhaps more decisively, the more significant reduction in lymphocyte count. The decrease in lymphocyte was more pronounced in patients who died in comparison to survivors (Figure). The number of neutrophils increased from $7.81 \pm 4.17$ to $9.39 \pm 4.17$ in surviving patients, and increased from $8.98 \pm 4.93$ to $12.1 \pm 4.92$ in deceased patients $(\mathrm{p}=0,001)$. Lymphocyte count decreased from $1.68 \pm 1.8$ to $1.1 \pm 0.73$ in surviving patients, whereas this decrease was more pronounced in patients who died: from $1.87 \pm 1.31$ to $0.79 \pm 0.52$ $(\mathrm{p}<0.001)$. As a result, the increase in NLR was much more pronounced in patients who died because of changes in these opposite directions. NLR value increased from $7.21 \pm 7.46$ to $12.46 \pm 10.83$ in survivors and from $10.37 \pm 14.61$ to $22.25 \pm 19.73$ in those who died $(\mathrm{p}<0.001)$.

Survival, or mortality, was not found to be significantly correlated with admission NLR, but definitely found to be linked to NLR at the $24^{\text {th }}$ of the event. This univariate finding (Table I) was tested in a multivariate environment with two models. In the first model, NLR-24th $(\beta=0.035$, OR 1.036 (1.002-1.071), $\mathrm{p}=0.040)$, hematoma volume at first CT $(\beta=0.012$, OR $1.012(0.999-1.024)$, $\mathrm{p}=0.067)$ and Hemphill score $(\beta=0.689$, OR 1.992 $(1.402-2.832) \quad p<0.001)$ were found to be significantly and independently related to in hospital mortality after adjusted to age (decade), AF, anticoagulant use and NLR-adm. In a second model in which STICH-2 PS was added instead of
Hemphill's score, again NLR-24th $(\beta=0.034$, OR $1.034(1.009-1.060) \mathrm{p}=0.008)$, in addition to STICH-2 PS $(\beta=0.022$, OR 1.022 (1.015-1.029), $\mathrm{p}<0.001$ ), were found to be as independent predictors of mortality.

Intracranial hematoma volume expansion greater than $12.5 \mathrm{cc}$ was detected in 46 (17\%) patients. In 60 patients $(22,2 \%)$, ICH volume increase was higher than 33\%. Features of patients with significant ICH expansion (either 12.5 cc or $33 \%$ increase) were summarized in Table II. In patients with $>12.5$ cc ICH expansion, aspirin use, anticoagulant use, initial ICH volume, lobar location, both Hemphill and STICH-II PS, and mortality rate were higher. In patients with $>33$ percent ICH expansion, anticoagulant use, aPTT, INR and ICH admission volume were higher and survival rate was lower (Table II).

Correlation between numerical NLR changes and ICH volume changes from admission to the end of the first day was, albeit weak, significantly positive $(r=0.273$, p two-tailed $<0.001)$. Patients with a hematoma expansion greater than $12.5 \mathrm{cc}$ had marginally lower lymphocyte count decrease (average change: $-1.05 \pm 0.88$ vs. $-0.74 \pm 1.02$, $\mathrm{p}=0.08$ ) and significantly higher neutrophil count increase $(4.85 \pm 5.56$ vs. $1.33 \pm 4.05, p=0.001)$. Similarly, those with hematoma expansion greater than $33 \%$ had significantly higher neutrophil increase $(3.85 \pm 5.49$ vs. $1.43 \pm 4.13, p=0.01)$ and borderline lymphocyte count decrease $(-1.05 \pm 1.0$ vs. $-0.72 \pm 0.99, \mathrm{p}=0.07$ ).

An exploratory logistic regression analysis indicated that hematoma expansion greater than $12.5 \mathrm{cc}$ correlated to, albeit borderline, NLR-24th $(\beta=0.038, \quad$ OR=1.038 $\quad$ (95\%CI: 1.008-1.069, $\mathrm{p}=0.012$ ) but not NLR-adm. The other determiners of hematoma expansion were aspirin use $(\beta=1.036, \quad O R=2.819 \quad$ (95\%CI: $1.136-6.996)$, $p=0.025)$; anticoagulant use $(\beta=1.127,0 R=3.086$ (95\%CI: 1.171-8.133), $\mathrm{p}=0.023)$; lobar location $(\beta=1.304, \quad O R=3.682 \quad$ (95\%CI: $1.456-9.311)$, $\mathrm{p}=0.006) ;$ Hemphill score $(\beta=0.427, \quad \mathrm{OR}=1.532$ (95\%CI: 1.058-2.218), $\mathrm{p}=0.024)$.No correlation between NLR-adm or NLR-24th and percental hematoma expansion $(<33 \%$ or $>33 \%)$ was observed. None of the univariate-significant determiners of hematoma expansion greater than $33 \%$ such as anticoagulant use, admission aPTT and 24th INR persisted in any exploratory multivariate modeling. 
Pektezel et al.

Table I. Comparison of survived and expired ICH patients.

\begin{tabular}{|c|c|c|c|c|}
\hline & & Survived & Expired & $p$ \\
\hline \multicolumn{2}{|l|}{ Age, years } & $64 \pm 13$ & $68 \pm 13$ & 0.003 \\
\hline \multicolumn{2}{|l|}{ Female } & $42 \%$ & $41 \%$ & 0.803 \\
\hline \multicolumn{2}{|l|}{ Hypertension } & $72 \%$ & $77 \%$ & 0.357 \\
\hline \multicolumn{2}{|l|}{ Diabetes } & $17 \%$ & $25 \%$ & 0.067 \\
\hline \multicolumn{2}{|c|}{ Hyperlipidemia } & $15 \%$ & $15 \%$ & 0.850 \\
\hline \multicolumn{2}{|c|}{ Atrialfibrillation } & $4 \%$ & $11 \%$ & 0.007 \\
\hline \multicolumn{2}{|l|}{ Smoking } & $16 \%$ & $12 \%$ & 0.301 \\
\hline \multicolumn{2}{|l|}{ Aspirin use } & $28 \%$ & $36 \%$ & 0.128 \\
\hline \multicolumn{2}{|c|}{ Clopidogreluse } & $4 \%$ & $7 \%$ & 0.283 \\
\hline \multicolumn{2}{|c|}{ Anticoagulantuse } & $9 \%$ & $20 \%$ & 0.003 \\
\hline \multicolumn{2}{|l|}{ Statinuse } & $8 \%$ & $9 \%$ & 0.623 \\
\hline \multicolumn{2}{|c|}{ Time-to-CT, minute } & $244 \pm 246$ & $267 \pm 204$ & 0.609 \\
\hline \multicolumn{2}{|c|}{ Admission ICH volume, cc } & $23.02 \pm 28.14$ & $53.21 \pm 45.22$ & $<0.001$ \\
\hline \multicolumn{2}{|c|}{ Follow-up ICH volume, cc } & $21.51 \pm 24.18$ & $64.29 \pm 46.4$ & $<0.001$ \\
\hline \multicolumn{2}{|c|}{ Volume increase, cc } & $2.25 \pm 8.38$ & $16.74 \pm 36.11$ & $<0.001$ \\
\hline \multicolumn{2}{|c|}{ Volume increase, \% } & $19.09 \pm 91.79$ & $239.03 \pm 1169.83$ & 0.020 \\
\hline \multirow{6}{*}{ ICH location } & Lobar & $32 \%$ & $36 \%$ & \\
\hline & Putamen & $23 \%$ & $23 \%$ & \\
\hline & Thalamus & $31 \%$ & $26 \%$ & \\
\hline & Cerebellar & $6 \%$ & $5 \%$ & 0.328 \\
\hline & Pons & $2 \%$ & $5 \%$ & \\
\hline & Other & $6 \%$ & $5 \%$ & \\
\hline \multicolumn{2}{|c|}{ Admission SBP, mmHg } & $176 \pm 41$ & $185 \pm 47$ & 0.097 \\
\hline \multicolumn{2}{|c|}{ Admission DBP, $\mathrm{mmHg}$} & $102 \pm 23$ & $105 \pm 24.7$ & 0.331 \\
\hline \multicolumn{2}{|c|}{ Admission heart rate } & $77 \pm 21$ & $82 \pm 26$ & 0.061 \\
\hline \multicolumn{2}{|c|}{ Admission NIHSS } & $11.4 \pm 10.1$ & $24.9 \pm 13.1$ & $<0.001$ \\
\hline \multicolumn{2}{|c|}{ Admission GCS } & $12.99 \pm 2.94$ & $8.7 \pm 4.31$ & $<0.001$ \\
\hline \multicolumn{2}{|l|}{ Hemphillscore } & $1.27 \pm 1.12$ & $2.66 \pm 1.22$ & $<0.001$ \\
\hline STICH-2 progr & core & $36.76 \pm 42.14$ & $-17.69 \pm 59.49$ & $<0.001$ \\
\hline Length of stay & & $19.81 \pm 25.31$ & $21.6 \pm 31.33$ & 0.557 \\
\hline Hematologica & ameters & & & \\
\hline Admission lym & & $1.68 \pm 1.08$ & $1.87 \pm 1.31$ & 0.144 \\
\hline Admission net & & $7.81 \pm 4.17$ & $8.98 \pm 4.93$ & 0.018 \\
\hline Admission NL & & $7.21 \pm 7.46$ & $10.37 \pm 14.61$ & 0.007 \\
\hline Admission leu & & $10.42 \pm 4.05$ & $11.75 \pm 4.87$ & 0.005 \\
\hline Admission her & & $41 \pm 4.92$ & $40.34 \pm 6.25$ & 0.257 \\
\hline Admission pla & & $244.49 \pm 71.82$ & $235.38 \pm 93.09$ & 0.289 \\
\hline Admission INF & & $1.32 \pm 1.9$ & $1.55 \pm 1.65$ & 0.252 \\
\hline Admission aP? & & $27.17 \pm 4.39$ & $29.34 \pm 8.35$ & 0.001 \\
\hline Follow-uplym & & $1.1 \pm 0.73$ & $0.79 \pm 0.52$ & $<0.001$ \\
\hline Follow-upneu & & $9.39 \pm 4.17$ & $12.1 \pm 4.92$ & $<0.001$ \\
\hline Follow-up NLI & & $12.46 \pm 10.83$ & $22.25 \pm 19.73$ & $<0.001$ \\
\hline Follow-upleuk & & $11.58 \pm 4.57$ & $14.07 \pm 5.11$ & $<0.001$ \\
\hline Follow-uphem & & $38.18 \pm 5.5$ & $39.5 \pm 26.19$ & 0.555 \\
\hline Follow-upplat & & $229.1 \pm 64.16$ & $219.31 \pm 82.48$ & 0.002 \\
\hline Follow-up INR & & $1.15 \pm 0.21$ & $1.45 \pm 0.44$ & $<0.001$ \\
\hline Follow-up aPT & & $27.57 \pm 5.16$ & $29.04 \pm 5.88$ & 0.270 \\
\hline
\end{tabular}

Abbreviations: Ad.: Admission, Afib: Atrial fibrillation, aPTT: activated partial thromboplastin time, CT: Computerized tomography of head, DBP: Diastolic blood pressure, FU: Follow-up, GCS: Glasgow Coma Scale Score, ICH: Intracranial hemorrhage, INR: international normalized ratio, NIHSS: The National Institutes of Health Stroke Scale, NLR: Neutrophil-to-lymphocyte ratio, SBP: Systolic blood pressure, STICH-2 PS: STICH-II prognostic score.

Turkish Journal of Cerebrovascular Diseases 2019; 25 (2): 118-124 
Table II. Intracerebral hematoma (ICH) expansion.

\begin{tabular}{|c|c|c|c|c|c|c|}
\hline & \multicolumn{2}{|c|}{ ICH expansion } & \multicolumn{4}{|c|}{ ICH expansion } \\
\hline & $\geq 12.5 \mathrm{cc}$ & $<12.5 \mathrm{cc}$ & $\mathbf{p}$ & $\geq 33 \%$ & $<33 \%$ & $p$ \\
\hline Age, years & $69 \pm 10$ & $65 \pm 13$ & 0.061 & $65 \pm 14$ & $66 \pm 13$ & 0.928 \\
\hline Female & $44 \%$ & $43 \%$ & 0.894 & $50 \%$ & $41 \%$ & 0.188 \\
\hline Hypertension & $74 \%$ & $75 \%$ & 0.917 & $80 \%$ & $73 \%$ & 0.304 \\
\hline Diabetes & $26 \%$ & $21 \%$ & 0.433 & $25 \%$ & $21 \%$ & 0.438 \\
\hline Hyperlipidemia & $30 \%$ & $18 \%$ & 0.060 & $27 \%$ & $18 \%$ & 0.139 \\
\hline Afib & $11 \%$ & $7 \%$ & 0.368 & $12 \%$ & $6 \%$ & 0.168 \\
\hline Smoking & $15 \%$ & $15 \%$ & 0.972 & $10 \%$ & $17 \%$ & 0.207 \\
\hline Aspirin use & $44 \%$ & $28 \%$ & 0.040 & $34 \%$ & $30 \%$ & 0.554 \\
\hline Clopidogreluse & $9 \%$ & $7 \%$ & 0.602 & $7 \%$ & $7 \%$ & 0.961 \\
\hline Anticoagulant & $31 \%$ & $11 \%$ & 0.001 & $31 \%$ & $10 \%$ & $<0.001$ \\
\hline Statinuse & $13 \%$ & $10 \%$ & 0.583 & $12 \%$ & $10 \%$ & 0.758 \\
\hline Time-to-CT, min & $276 \pm 231$ & $256 \pm 242$ & 0.729 & $220 \pm 204$ & $270 \pm 249$ & 0.289 \\
\hline ICH volume, cc & $41.4 \pm 31.8$ & $25.2 \pm 28.7$ & 0.001 & $20.3 \pm 18.5$ & $30.2 \pm 32.1$ & 0.024 \\
\hline Lobar ICH & $48 \%$ & $27 \%$ & 0.006 & $27 \%$ & $32 \%$ & 0.438 \\
\hline Putamen ICH & $26 \%$ & $23 \%$ & 0.676 & $23 \%$ & $24 \%$ & 0.939 \\
\hline Thalamus ICH & $22 \%$ & $33 \%$ & 0.146 & $35 \%$ & $30 \%$ & 0.418 \\
\hline Admission SBP & $179 \pm 38$ & $184 \pm 42$ & 0.537 & $186 \pm 47$ & $182 \pm 40$ & 0.642 \\
\hline Admission DBP & $102 \pm 20$ & $104 \pm 24$ & 0.699 & $107 \pm 26$ & $102 \pm 23$ & 0.153 \\
\hline Hemphill score & $2.05 \pm 1.23$ & $1.53 \pm 1.24$ & 0.015 & $1.55 \pm 1.17$ & $1.64 \pm 1.27$ & 0.644 \\
\hline STICH-2 PS & $12.54 \pm 49.36$ & $37.33 \pm 49.3$ & 0.002 & $37.4 \pm 41.3$ & $31.88 \pm 52.36$ & 0.453 \\
\hline ength of stay, day & $24 \pm 32$ & $24 \pm 35$ & 0.873 & $26 \pm 32$ & $23 \pm 35$ & 0.572 \\
\hline Survival & $30 \%$ & $73 \%$ & $<0.001$ & $42 \%$ & $71 \%$ & $<0.001$ \\
\hline Ad. lymphocyte & $2 \pm 1.56$ & $1.78 \pm 1.12$ & 0.283 & $2.1 \pm 1.45$ & $1.74 \pm 1.12$ & 0.051 \\
\hline Ad. neutrophil & $6.13 \pm 3.84$ & $7.88 \pm 4.14$ & 0.014 & $6.09 \pm 4.16$ & $8 \pm 4.04$ & 0.003 \\
\hline Ad. NLR & $8.56 \pm 16.26$ & $7.26 \pm 8.28$ & 0.450 & $5.39 \pm 8.73$ & $8.03 \pm 10.23$ & 0.087 \\
\hline Ad. leukocyte & $8.92 \pm 3.64$ & $10.68 \pm 4.71$ & 0.018 & $9.01 \pm 4.31$ & $10.77 \pm 4.6$ & 0.008 \\
\hline Ad. hematocrit & $39 \pm 5.5$ & $41 \pm 5.6$ & 0.042 & $39.6 \pm 5.7$ & $41 \pm 5.5$ & 0.114 \\
\hline Ad. Platelet & $228 \pm 89$ & $231 \pm 75$ & 0.794 & $235 \pm 83$ & $230 \pm 76$ & 0.619 \\
\hline Admission INR & $1.78 \pm 1.39$ & $1.38 \pm 2.13$ & 0.228 & $1.63 \pm 1.01$ & $1.4 \pm 2.24$ & 0.448 \\
\hline Admission aPTT & $31.68 \pm 8.6$ & $26.99 \pm 5.68$ & $<0.001$ & $30.57 \pm 8.15$ & $26.99 \pm 5.72$ & 0.002 \\
\hline FU lymphocyte & $0.81 \pm 0.53$ & $1.07 \pm 0.74$ & 0.060 & $0.87 \pm 0.55$ & $1.06 \pm 0.75$ & 0.141 \\
\hline FU neutrophil & $11.26 \pm 5.15$ & $9.35 \pm 4.09$ & 0.022 & $10.45 \pm 5.47$ & $9.47 \pm 3.98$ & 0.208 \\
\hline FU NLR & $20.73 \pm 22.63$ & $12.97 \pm 11.62$ & 0.005 & $16.21 \pm 10.52$ & $13.83 \pm 15.3$ & 0.357 \\
\hline FU leukocyte & $12.78 \pm 5.51$ & $11.57 \pm 4.86$ & 0.206 & $12.25 \pm 5.66$ & $11.65 \pm 4.8$ & 0.499 \\
\hline FU hematocrit & $43.61 \pm 46.35$ & $37.76 \pm 6.03$ & 0.129 & $42.71 \pm 42.16$ & $37.72 \pm 5.94$ & 0.163 \\
\hline FU platelet & $226 \pm 76$ & $212 \pm 70$ & 0.533 & $224 \pm 71$ & $218 \pm 71$ & 0.675 \\
\hline FU INR & $1.58 \pm 0.4$ & $1.2 \pm 0.29$ & $<0.001$ & $1.45 \pm 0.43$ & $1.19 \pm 0.26$ & 0.002 \\
\hline FU aPTT & $30.59 \pm 5.35$ & $26.82 \pm 4.53$ & 0.008 & $30.39 \pm 6.1$ & $26.26 \pm 3.64$ & 0.453 \\
\hline
\end{tabular}

Abbreviations: Ad.: Admission, Afib: Atrial fibrillation, aPTT: activated partial thromboplastin time, CT: Computerized tomography of head, DBP: Diastolic blood pressure, FU: Follow-up, ICH: Intracranial hemorrhage, INR: international normalized ratio, NLR: Neutrophil-to-lymphocyte ratio, SBP: Systolic blood pressure, STICH-2 PS: STICH-II prognostic score.

\section{DISCUSSION}

In this study, we demonstrated that only NLR values obtained at the end of the first day were associated with in-hospital mortality. However, admission NLR values were not linked to inhospital mortality. In previous researches, albeit not all (11), admission NLR has been shown to be associated with both mortality and early or late functional outcomes $(7,12,13)$. There may be various mechanisms for positive association between NLR and short-term mortality in the patients with acute ICH. Intracerebral hematomamediated immunodepression, or neurogenic immunodepression in brief term, is the first mechanism that comes to mind. Decrease of 


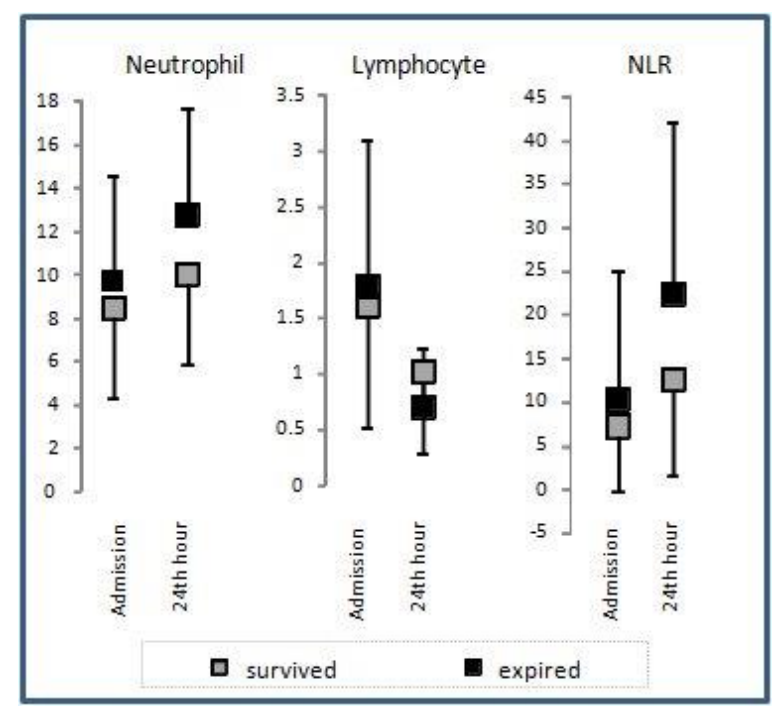

Figure. Changes of Neutrophil count, lymphocyte count and NLF from admission to 24th hour.

lymphocyte count, resulting in proportional increase of NLR, is a characteristic feature of neurogenic immunodepression and closely related to stroke-associated pneumonia which is one of the major contributors of mortality in this population (14). The second mechanism is early systemic inflammatory response triggered by ICH components (15). The resulting neutrophilia, which will lead to an increase in NLR, can enhance secondary tissue damage in the hemorrhagic brain. The third, and perhaps more credible, mechanism is hypothalamic-pituitary-adrenal axis hyperactivity occurring in patients with ICH after hyperacute phase (16). The stress reaction triggered by increased levels of cortisol or catecholamines result in typical neutrophilia and lymphocytopenia, causing significant NLR increase. Increased stress response is connected to poor prognosis. This may be because both the stress reaction correlates with excess tissue damage, which already is associated with poor prognosis. That is, it is an epiphenomenon with poor prognosis. Or, the stress reaction exerts a direct negative effect on the course of the event.

In our study, we found that NLR increase was parallel to hematoma volume increase. But, the relationship wasn't very robust. It only showed a weak, but independent, link between NLR at 24th hour and ICH enlargement of more than $12.5 \mathrm{cc}$. In the literature, there is no direct and supportive potent data on association between expansion of hematoma and NLR. In a previous study (17), intracerebral hematoma expansion was found inversely correlated with higher admission leukocyte and neutrophil counts, whereas there was no correlation with lymphocyte count. But, NLR was not examined in this study. In a more recent study (18), it was found that NLR was associated with 'Island Sign', which reflects increased risk of intracerebral hematoma expansion. However, a multivariate analysis did not document an independent connection of NLR to hematoma expansion.

Our study has some minor limitations. First of all, its retrospective nature caused exclusion of some patients due to inadequacy of data. No data about infectious status were collected. Moreover, cause of death was not pursued. Without these, further interpretation of the results would have perhaps been possible. Now, this is up to future work on this issue.

\section{REFERENCES}

1. Feigin VL, Lawes CM, Bennett DA, Anderson CS. Stroke epidemiology: a review of population-based studies of incidence, prevalence, and case-fatality in the late 20th century. Lancet Neurol. 2003; 2: 43-53.

2. Zhou Y, Wang Y, Wang J, Anne Stetler R, Yang QW. Inflammation in intracerebral hemorrhage: from mechanisms to clinical translation. Prog Neurobiol. 2014; 115: 25-44.

3. Tamhane UU, Aneja S, Montgomery D, Rogers EK, Eagle KA, Gurm HS. Association between admission neutrophil to lymphocyte ratio and outcomes in patients with acute coronary syndrome. Am J Cardiol. 2008; 102: 653-657.

4. Tokgoz S, Kayrak M, Akpinar Z, Seyithanoglu A, Guney F, Yuruten B. Neutrophil lymphocyte ratio as a predictor of stroke. J Stroke Cerebrovasc Dis. 2013; 22: 1169-1174.

5. Pektezel MY, Yilmaz E, Arsava EM, Topcuoglu MA. Neutrophil-to-Lymphocyte Ratio and Response to Intravenous Thrombolysis in Patients with Acute Ischemic Stroke. J Stroke Cerebrovasc Dis. 2019; 28: 1853-1859.

6. Templeton AJ, McNamara MG, Seruga B, Vera-Badillo FE, Aneja P, Ocana A, et al. Prognostic role of neutrophil-tolymphocyte ratio in solid tumors: a systematic review and meta-analysis. J Natl Cancer Inst. 2014; 106: dju124.

7. Qin J, Li Z, Gong G, Li H, Chen L, Song B, et al. Early increased neutrophil-to-lymphocyte ratio is associated with poor 3-month outcomes in spontaneous intracerebral hemorrhage. PLoS One. 2019; 14: e0211833.

8. Hemphill JC, 3rd, Bonovich DC, Besmertis L, Manley GT, Johnston SC. The ICH score: a simple, reliable grading scale for intracerebral hemorrhage. Stroke. 2001; 32: 891-897.

9. Mendelow AD, Gregson BA, Rowan EN, Murray GD, Gholkar A, Mitchell PM, et al. Early surgery versus initial conservative treatment in patients with spontaneous supratentorial lobar intracerebral haematomas (STICH II): a randomised trial. Lancet. 2013; 382: 397-408.

10. Kothari RU, Brott T, Broderick JP, Barsan WG, Sauerbeck LR, Zuccarello $M$, et al. The ABCs of measuring intracerebral hemorrhage volumes. Stroke. 1996; 27: 13041305. 
11. Sun Y, You S, Zhong C, Huang Z, Hu L, Zhang X, et al. Neutrophil to lymphocyte ratio and the hematoma volume and stroke severity in acute intracerebral hemorrhage patients. Am J Emerg Med. 2017; 35: 429-433.

12. Lattanzi S, Cagnetti C, Provinciali L, Silvestrini M. Neutrophil-to-Lymphocyte Ratio Predicts the Outcome of Acute Intracerebral Hemorrhage. Stroke. 2016; 47: 16541657.

13. Wang F, Hu S, Ding Y, Ju X, Wang L, Lu Q, et al. Neutrophilto-Lymphocyte Ratio and 30-Day Mortality in Patients with Acute Intracerebral Hemorrhage. J Stroke Cerebrovasc Dis. 2016; 25: 182-187.

14. Liu DD, Chu SF, Chen C, Yang PF, Chen NH, He X. Research progress in stroke-induced immunodepression syndrome (SIDS) and stroke-associated pneumonia (SAP). Neurochem Int. 2018; 114: 42-54.
15. Lattanzi S, Brigo F, Trinka E, Cagnetti C, Di Napoli M, Silvestrini M. Neutrophil-to-Lymphocyte Ratio in Acute Cerebral Hemorrhage: a System Review. Transl Stroke Res. 2019; 10: 137-145.

16. Yang X, Ren W, Zu H, Dong Q. Evaluate the serum cortisol in patients with intracerebral hemorrhage. Clin Neurol Neurosurg. 2014; 123: 127-130.

17. Morotti A, Phuah CL, Anderson CD, Jessel MJ, Schwab K, Ayres AM, et al. Leukocyte Count and Intracerebral Hemorrhage Expansion. Stroke. 2016; 47: 1473-1478.

18. Zhang F, Qian J, Tao C, Wang Y, Lin S, You C, et al. Neutrophil to lymphocyte ratio predicts island sign in patients with intracranial hemorrhage. Medicine (Baltimore). 2018; 97: e13057. 